\title{
Differential Pulse Polarography Procedure for the Estimation of Deferoxamine in Pharmaceuticals
}

\author{
SALAM A.H. AL-AMERI and BAYAN H.A. AL-AMERI* \\ Department of Chemistry, College of Science, Al-Mustansiriyah University, Baghdad, Iraq \\ bayanalamry@yahoo.com
}

Received 1 October 2017 / Accepted 19 October 2017

\begin{abstract}
A differential pulse polarography procedure has been developed and applied for the determination of deferoxamine in dosage form with $\mathrm{DME}$ versus $\mathrm{Ag} / \mathrm{AgCl}$. The best peak response was establish at $-1.63 \mathrm{~V}$ in $0.04 \mathrm{M} \mathrm{B}-\mathrm{R}$ buffer at $\mathrm{pH} 2$ and $0.1 \mathrm{M} \mathrm{KCl}$ as supporting electrolyte with two electrons transferred in irreversible process. In the best conditions, Beer's law was perform with in the concentration range of $0.01-0.05 \mu \mathrm{g} \cdot \mathrm{mL}^{-1}$ with a correlation coefficient, $\mathrm{r}=9985$. The obtaining LOD and LOQ was 0.0024 and $0.0081 \mu \mathrm{g} \cdot \mathrm{mL}^{-1}$, the precision, \%RSD ranged between $0.34-1.24 \%$. Another DPP method has been proposed for the estimation as deferoxamine-Fe complex which gave best DDP response at $-0.385 \mathrm{~V}$ in $0.1 \mathrm{M}$ acetate buffer at $\mathrm{pH} 4$ and $0.01 \mathrm{M} \mathrm{KCl}$ as supporting electrolyte. The calibration graph was linear at a concentration range $1.25 \times 10^{-6}-2.5 \times 10^{-5} \mathrm{M}$ with $\mathrm{r}=9985$ also a superb analytical merit numbers were found, LOD of $0.7 \times 10^{-6} \mathrm{M}$ and the LOQ of $2.32 \times 10^{-6} \mathrm{M}$ with RSD\% ranged from $0.27-0.66 \%$. The formation of this colored complex at $1: 1$ mole ratio calculated by UV-Vis spectrophotometry at $\lambda_{\max }=468 \mathrm{~nm}$ in aqueous medium. The established DPP methods offers excellent analytical figures of merits as well as applied to examine the commercial drug Desferal ${ }^{\mathrm{TM}}$ vial for the determination of deferoxamine and found to be $490.6 \mathrm{mg} / \mathrm{unit}$ compared to the stated value of $500 \mathrm{mg} / \mathrm{unit}$.
\end{abstract}

Keywords: DPP, Deferoxamine, Fe, Complex

\section{Introduction}

Deferoxamine (DFOA), sell under the brand name desferal; deferoxamine, $\mathrm{C}_{25} \mathrm{H}_{48} \mathrm{~N}_{6} \mathrm{O}_{8}$, 560.69 g.mol ${ }^{-1}, \quad$ is an $N^{\prime}$-[5-(acetyl-hydroxyl-amino)pentyl]- $N$-[5-[3-(5-aminopentylhydroxy-carbamoyl)propanoylamino]pentyl]- $N$-hydroxy-butane diamide ${ }^{1}$ (Figure 1).<smiles>CC(=O)N(O)CCCCCNC(=O)CCC(=O)N(O)CCCCCNC(=O)CCC(=O)N(O)CCCCCN</smiles>

Figure 1. Chemical structure of deferoxamine

Deferoxamine effectively chelates with iron and other metals ${ }^{2}$, therefore it has been used to remove complex iron through the kidney in patients with iron excess by forming a stable complex that avoid the iron from inflowing in to more chemical reactions ${ }^{3}$. In addition, it's also forms a complex with aluminum ${ }^{4}$, so this chelator has been used in the treatment 
of aluminum accumulation and toxicity in dialysis patients ${ }^{5}$. Various techniques have been used for the determination of deferoxamine include spectrophotometry ${ }^{6}{ }^{7}$ HPLC $^{8,9}$.

The cyclic voltammetry, $\mathrm{CV}$ at $\mathrm{HMDE}$ and DPP modes versus $\mathrm{Ag} / \mathrm{AgCl}$ was applied for deferoxamine voltammetric estimation. The reduction potential was raises when the $\mathrm{pH}$ was drop off from 9.0 to 3.5 . CV mode shows a one-electron reversible reduction ${ }^{10}$ at $-0.71 \mathrm{~V}$ in borate buffer at $\mathrm{pH}$ 9.0. An anodic stripping voltammetric mode for the estimation of deferoxamine, alendronate sodium and lisinopril was described; this method is based on the formation of stable drug-copper complex when mixing with copper phosphate suspension. The reduction peaks which related to the reduction of the copper(II) moiety of the formed complexes are obtained at $-153,-74$ and $-111 \mathrm{mV}$ respectively. The limit of detection was as low ${ }^{11}$ as 8.6 ng. $\mathrm{mL}^{-1}$.

The purpose of this work is to confirm the polarographic behaviour of the mentioned drug and to improve a simple and sensitive polarographic method for their determination in pharmaceuticals.

\section{Experimental}

Electrochemical measurements were performed by a 797VA computrace metrohm, Herisau, Switzerland polarographic analyser. It was used with DME mode as a working electrode and $\mathrm{Ag} / \mathrm{AgCl}$ as a reference electrode with $\mathrm{Pt}$ wire while auxiliary electrode. All spectral and absorbance measurements during this study were done using a digital recording doublebeam LABOMED, INC (USA) UV-Visible 2960 spectrophotometer operation at wavelength of 190-1100 nm equipped with $1 \mathrm{~cm}$ optical path quartz cell. All experiments were performed at $25^{\circ} \mathrm{C}$.

\section{Materials and reagents}

All experiments were achieved with analytical grade reagent, chemicals and solvents. Deionised water was employ for preparation the standard and samples. Deferoxamine standard material was provided from the Novartis pharma AG, deferral vial $500 \mathrm{mg}$ was obtained from local pharmacies.

The standard solution of deferoxamine at $250 \mu \mathrm{g} \cdot \mathrm{mL}^{-1}$ and $10^{-3} \mathrm{M}$ for the direct and deferoxamine-Fe complex analysis was prepared by disolving of 12.5 and $32.8 \mathrm{mg}$ of standard deferoxamine in a minimum amount of deionised water in $50 \mathrm{~mL}$ volummetric flask and completed to mark with deionised water. Diluted 50, 5 and $1 \mu \mathrm{g} \cdot \mathrm{mL}^{-1}$ standard solution deferoxamine was prepared by transferring $10 \mathrm{~mL}$ from $250 \mu \mathrm{g} . \mathrm{mL}^{-1}$ standard solution, $5 \mathrm{~mL}$ from $50 \mu \mathrm{g} \cdot \mathrm{mL}^{-1}$ standard solution to $50 \mathrm{~mL}$ volummetric flask and diluted to the mark with deionised water. Diluted $1 \mu \mathrm{g} . \mathrm{mL}^{-1}$ standard solution of deferoxamine was prepared by transferring $10 \mathrm{~mL}$ from $5 \mu \mathrm{g} \cdot \mathrm{mL}^{-1}$ standard solution to $50 \mathrm{~mL}$ volummetric flask and diluted to the mark with deionised water. Diluted $10^{-4} \mathrm{M}$ standard solution of deferoxamine was prepared by transferring $5 \mathrm{~mL}$ from $10^{-3} \mathrm{M}$ solution to $50 \mathrm{~mL}$ volummetric flask and completed to the mark with deionised water.

A $10^{-3} \mathrm{M}$ standard solutions of ferric nitrate was prepared by disolving $5.9 \mathrm{mg}$ of standard ferric chlorid in $50 \mathrm{~mL}$ deionised water. Diluted $10^{-4} \mathrm{M}$ solutions of ferric nitrate was prepared by transferring $5 \mathrm{~mL}$ from $10^{-3} \mathrm{M}$ solution to $50 \mathrm{~mL}$ volummetric flask and completed to the mark with deionised water. $1 \mathrm{M}$ potassium chlorid, lithum chloride and potassium nitrate solutions was prepared by dissolved $7.45 \mathrm{~g}, 4.239 \mathrm{~g}$ and $10.1 \mathrm{~g}$ respectively in $100 \mathrm{~mL}$ of deionized water. 
Acetate buffer solution, $0.1 \mathrm{M}$ was prepared by mixing $9 \mathrm{~mL}$ of $0.1 \mathrm{M}$ sodium acetate with $41 \mathrm{~mL}$ of $0.1 \mathrm{M}$ acetic acid and completed to volume $100 \mathrm{~mL}$ with deionized water ${ }^{12}$. B-R buffer, $0.04 \mathrm{M}$ solution was prepared by disolving $2.47 \mathrm{~g}$ of boric acid in $500 \mathrm{~mL}$ deionised water in $1000 \mathrm{~mL}$ volummetric flask then added $2.3 \mathrm{~mL}$ acetic acid and $2.7 \mathrm{~mL}$ phosphoric acid and complete the volume to the mark with deionised water.

\section{General DPP}

\section{Deferoxamine}

An aliquot volume of deferoxamine samples was transferred to $25 \mathrm{~mL}$ volumetric flasks, then $2 \mathrm{~mL}$ of $0.04 \mathrm{M} \mathrm{B}-\mathrm{R}$ buffer at $\mathrm{pH} 2$ was added with $2.5 \mathrm{~mL}$ of $\mathrm{KCl}$ as supporting electrolyte and diluted to the mark with deionized water. Each sample was transfered to a polarographic cell and degassed with high purity nitrogen for $300 \mathrm{~s}$ to purge the oxygen and analysis at scan rate $5 \mathrm{mVs}^{-1}$ with pulse amplitude 50 .

\section{Deferoxamine-Fe complex}

An aliquot volume of deferoxamine was transferred to $25 \mathrm{~mL}$ volumetric flasks then $5 \mathrm{~mL}$ $10^{-4} \mathrm{M}$ ferric nitrate solution was added and $2 \mathrm{~mL}$ of $0.1 \mathrm{M}$ acetate buffer at $\mathrm{pH} 4$ with $0.250 \mathrm{~mL}$ of $\mathrm{KCl}$ as supporting electrolyte and diluted to the mark with deionized water. Each sample was transfered to a polarographic cell and degassed with high purity nitrogen for $300 \mathrm{~s}$ to purge the oxygen and analysis at scan rate $5 \mathrm{mV} \mathrm{s}^{-1}$ with pulse amplitude 50 .

\section{Determination of Deferoxamine : Metal ratio}

The deferoxamine : metal ratio was determined in deionized water using Job method ${ }^{13}$. A series of solutions was prepared, each one containing the similar total number of deferioxamine and $\mathrm{Fe}(\mathrm{III})$ moles but each one contain a different ratio of deferoxamine to $\mathrm{Fe}(\mathrm{III})$ moles.

\section{Preparation of the calibration curve of deferoxamine}

A series of nine standard solutions ranged between $0.01-0.05 \mu \mathrm{g} \cdot \mathrm{mL}^{-1}$ daily prepared by transfer volumes $0.25-1.25 \mathrm{~mL}$ of $1 \mu \mathrm{g} \cdot \mathrm{mL}^{-1}$ deferoxamine standard solution in $25 \mathrm{~mL}$ volumetric flask with $2 \mathrm{~mL}$ of $0.04 \mathrm{M} \mathrm{B}-\mathrm{R}$ buffer at $\mathrm{pH} 2$ and $2.5 \mathrm{~mL}$ of $1 \mathrm{M} \mathrm{KCl}$ as supporting electrolyte, then diluted to the mark with deionized water. Each standard solution was analysis using suggested DPP method in the optimal conditions. A standard calibration graph were prepared between $i_{d}$ obtained for deferoxamine against the concentration using the least squares method ${ }^{14}$.

\section{Preparation the calibration curve of Deferoxamine-Fe complex}

A series of $1.25 \times 10^{-6}, 2.5 \times 10^{-6}, 5 \times 10^{-6}, 1 \times 10^{-5}, 1.5 \times 10^{-5}, 2 \times 10^{-5}$ and $2.5 \times 10^{-5} \mathrm{M}$ of stansard solutions were daily prepared by transferring $0.25,0.5,1,2,3,4$ and $5 \mathrm{~mL}$ of $10^{-4} \mathrm{M}$ deferoxamine solution with $5 \mathrm{~mL} 10^{-4} \mathrm{M}$ ferric nitrate solution in $25 \mathrm{~mL}$ volummetic flasks and $2 \mathrm{~mL}$ of $0.1 \mathrm{M}$ acetate buffer at $\mathrm{pH} 4$ and $0.250 \mathrm{~mL}$ of $1 \mathrm{M} \mathrm{KCl}$ as supporting electrolyte then diluted to the mark with deionized water. Each solution was transfered to a polarographic cell and analysis using developed DPP method in the optimum setting. A standard calibration graph for deferoxamine in the concentration range from $1.25 \times 10^{-6}$ to $2.5 \times 10^{-5} \mathrm{M}$ were prepared between $\mathrm{i}_{\mathrm{d}}$ find beside the concentration using the least squares method $^{14}$.

\section{Analysis of desferal vial samples}

A 5 vial contents were mixed and $25 \mu \mathrm{g}$ were weighed and transferred to a $25 \mathrm{~mL}$ volumetric flask and diluted to the mark with deionized water. Appropriate solutions were 
prepared by taking suitable aliquots and diluting them with deionized water. Each sample were analysed using developed DPP.

\section{Results and Discussion}

\section{Optimization of DPP}

The effects of a number of experimental factors which impact the DPP effectiveness were carried out by one variable at a time optimization, whereas just one factor is changed and the others are kept at a steady rank. The effect of $\mathrm{pH}$ solutions, buffers and supporting electrolyte were chosen in this work.

\section{Polarographic measurments}

DPP technique was applied for the analysis of deferoxamine. The DPP technique was the most sensitive than other technique. The effect of $\mathrm{pH}$ at valuese ranged between 2 to 9 was examined with different buffer solutions, its essential to buffer solutions in organic voltammetry, since mainly organic electrode process create hydrogen ions, if not buffered solutions are used, $\mathrm{pH}$ value changes can occur as the reaction proceed ${ }^{13}$. Deferoxamine has been appear one reduction peak in acidic, natural and alkali media, this peak shifted to additional negative potential with $\mathrm{pH}$ increase, Figure 2.

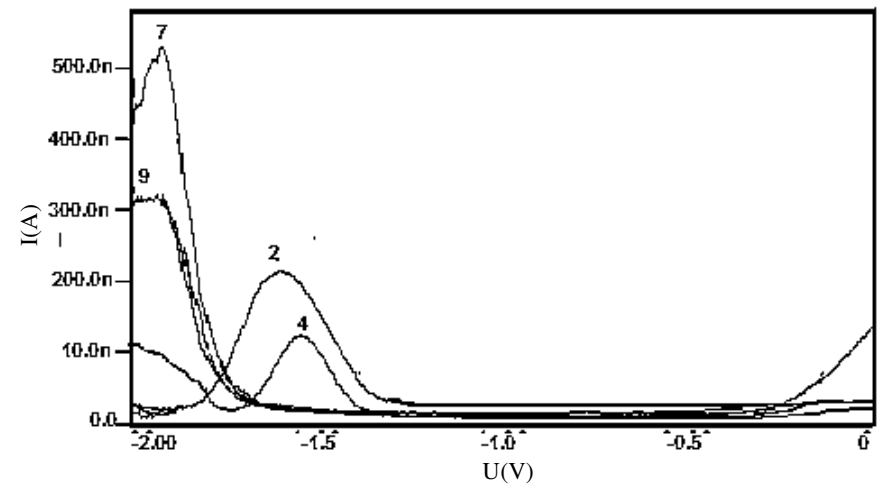

Figure 2. DPP polarograms of deferoxamine at different $\mathrm{pH}$ solutions

Deferoxamine showed a distinguished peak at $-1.63 \mathrm{~V}$ applied potential versus $\mathrm{Ag} / \mathrm{AgCl}$ in $0.04 \mathrm{M} \mathrm{B}-\mathrm{R}$ buffer at $\mathrm{pH} 2$ as a best buffer solution, also $0.1 \mathrm{M} \mathrm{KCl}$ was found to be the most excellent supporting electrolyte compared with $\mathrm{KNO}_{3}$ and $\mathrm{LiCl}$, Figure 3.

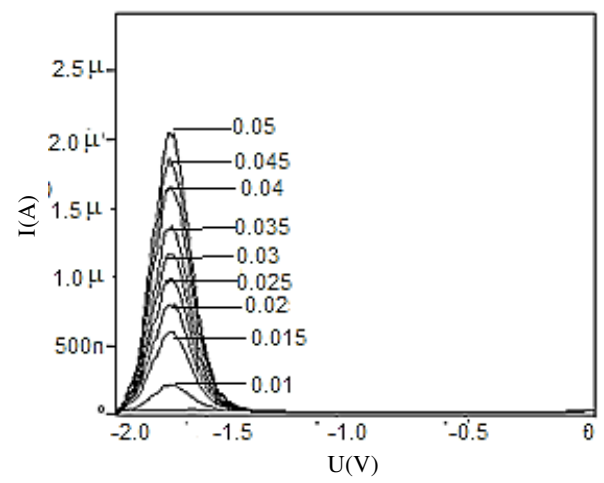

Figure 3. DPP polarograms of deferoxamine at different concentrations 
DPP analysis of deferoxamine-Fe(III) complex illustrate a various peak reduction potential as $\mathrm{pH}$ solution increased from 2 to 9 (Figure 4), also the reduction peak was shifted to more negative potential which means more difficult than in acidic and neutral media since the organic reduction including hydrogen ion which is a little sum in the alkali media compared with other media ${ }^{15}$.

Deferoxamine-Fe complex showed a distinguished peak at $-0.385 \mathrm{~V}$ applied potential in $0.1 \mathrm{M}$ acetate buffer at $\mathrm{pH} 4$ as establish to be the finest buffer solution and $0.01 \mathrm{M} \mathrm{KCl}$ was prove to be the best supporting electrolyte compared with $\mathrm{KNO}_{3}$ and $\mathrm{LiCl}$ (Figure 5). The results showed that well-defined polarograms and relatively high peak currents were obtained when scan rate $5 \mathrm{mVs}^{-1}$ with pulse amplitude 50 . The results demonstrate that welldefined polarograms and quite high peak currents were obtained.

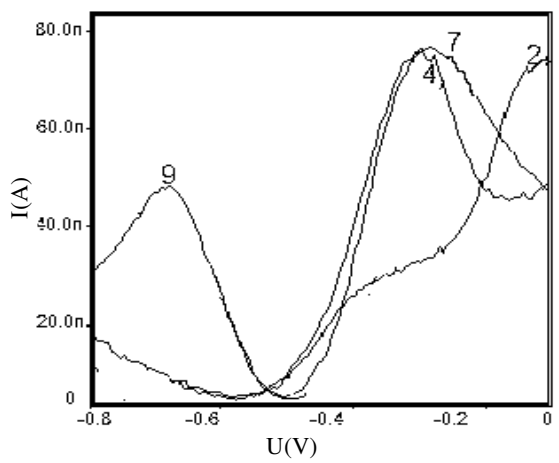

Figure 4. DPP polarograms of deferoxamine-Fe complex in different $\mathrm{pH}$ solutions

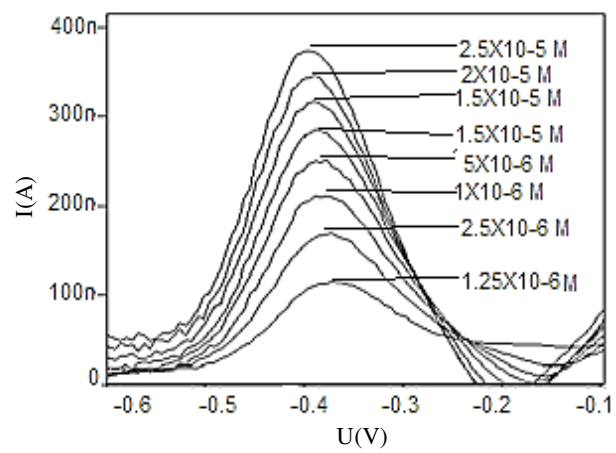

Figure 5. DPP polarograms of deferoxamine-Fe complex at different concentrations

The absorption spectra for the deferoxamine drug and its $\mathrm{Fe}^{3+}$ - complex against blank solution prepared under comparable conditions illustrate that the absorption maximum, $\lambda_{\max }$ of deferoxamine drug alone occurs in $252 \mathrm{~nm}$ while the Fe(III) reagent alone displays an $\lambda_{\max }$ at $330 \mathrm{~nm}$ and deferoxamine-Fe complex appeared $\lambda_{\max }$ at $468 \mathrm{~nm}$, then a wavelength maximum at $468 \mathrm{~nm}$ for the complex was used all over this work (Figure 6).

The deferoxamine : metal ratio was determined using Job method, the results of L:M showed that the ratio was 1:1 which obtained by plotting the absorbance of the complex solution at $468 \mathrm{~nm}$ varies the mole fraction of the metal, $\mathrm{VM} /(\mathrm{VM}+\mathrm{VL})$ (Figures 7 and 8).

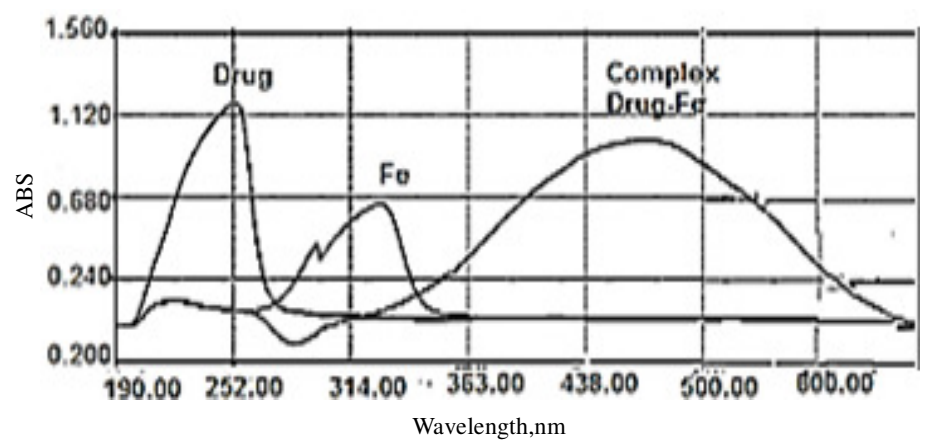

Figure 6. Absorption spectra of deferoxamine, Fe(III) and deferoxamine-Fe complex solutions 


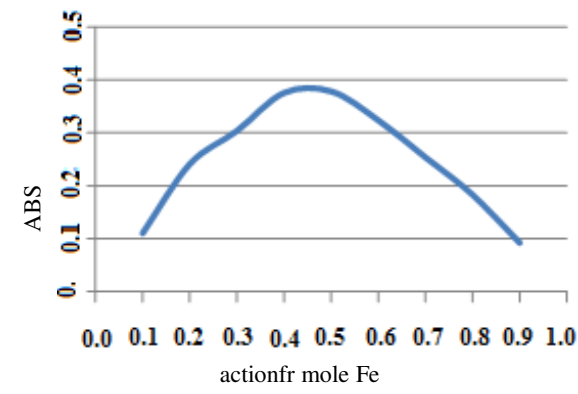

Figure 7. Job's plot of deferoxamine-Fe complex

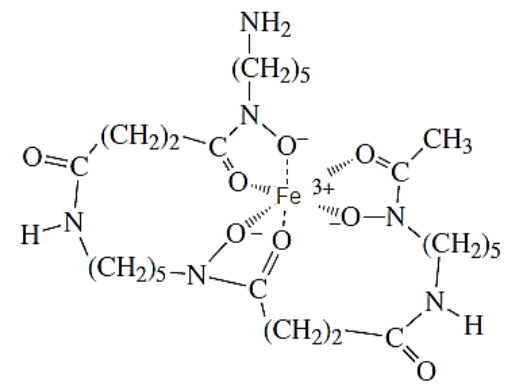

Figure 8. Suggested deferoxamine-Fe complex structure

\section{Method validation}

Under the optimized conditions, the graphical management of the peak current obtained for deferoxamine and deferoxamine-Fe complex was achieve by plotting the peak current beside the concentration of analyte solutions (Figures 9 and 10).
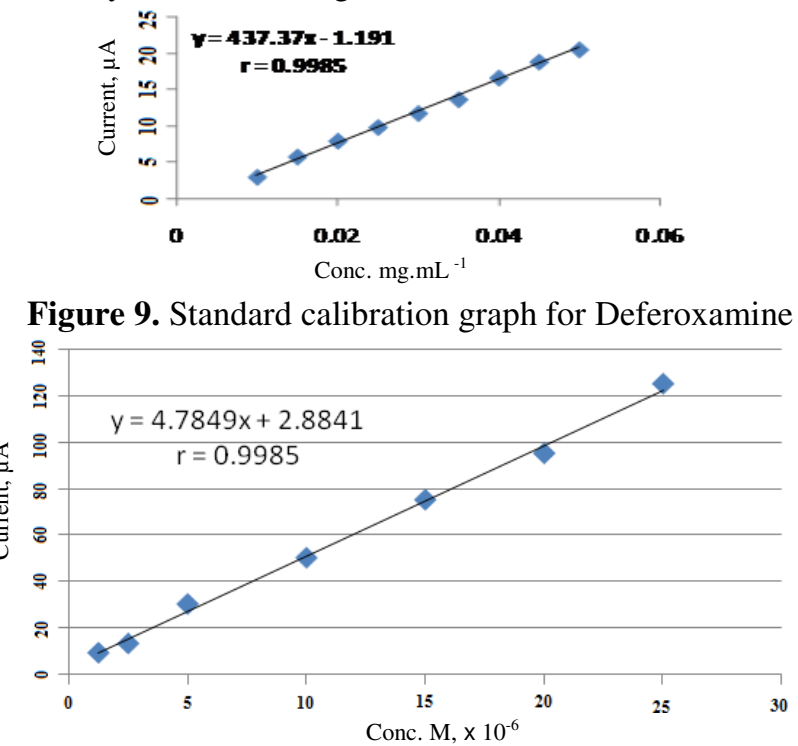

Figure 10. Standard calibration graph for deferoxamine-Fe complex

The numerical estimation for the calibration graph exposed that the linear regression equations for analyte are statistically suitable. The prediction based on the regression line is acceptable as listed in Tables 1 and 2; this regression line is used to estimate the deferoxamine concentrations in the selected samples which appear justified on statistical basis.

The limit of detection (LOD) and the limit of quantification (LOQ) for deferoxamine and deferoxamine-Fe complex estimated based on the standard deviation of the response, residual standard deviation $S_{\mathbf{y} / \mathbf{x}}$ and the slope $b$ of the calibration curve using the equations $\left(\mathrm{a}+3 \mathrm{~S}_{\mathbf{y} / \mathbf{x}}\right)$ and $\left(\mathrm{a}+10 \mathrm{~S}_{\mathbf{y} / \mathbf{x}}\right)$ respectively ${ }^{14}$. The results obtained by the projected methods is in agreement with a few but greatly better than obtained with mainly methods in literature, the results show that the LOD and LOQ found for deferoxamine was equal to 0.005 and $0.0165 \mu \mathrm{g} . \mathrm{mL}^{-1}$ while $0.1 \times 10^{-6}$ and $0.3 \times 10^{-6} \mathrm{M}$ for deferoxamine-Fe complex. 
Table 1. Analytical numbers of merit of the deferoxamine estimation using DPP methods

\begin{tabular}{lc}
\hline Parameters & Values \\
\hline Peak potential, $\mathrm{E}_{\mathrm{p}}(\mathrm{V})$ & -1.63 \\
Concentration range, $\mu \mathrm{g} \cdot \mathrm{mL}^{-1}$ & $0.01-0.05$ \\
Regression equation $\mathrm{y}=\mathrm{bx}-\mathrm{a}$ & $\mathrm{Y}=437.37 \mathrm{x}+1.191$ \\
Correlation coefficient ${ }^{\circ}$ & 0.9985 \\
Linearity $\left(\mathrm{R}^{2}\right)$ & 0.9971 \\
Slop $(\mathrm{b})$ & 437.37 \\
Intercept (a) & 1.191 \\
Standard deviation of regression line $\left(\mathrm{S}_{\mathrm{y} / \mathrm{x}}\right)$ & 0.3537 \\
Standard deviation of intercept $\left(\mathrm{S}_{\mathrm{a}}\right)$ & 0.262 \\
Standard deviation of slope $\left(\mathrm{S}_{\mathrm{b}}\right)$ & 9.057 \\
C.L. for the intercept $\left(\mathrm{a} \pm \mathrm{ts} \mathrm{s}_{\mathrm{a}}\right)$ at $95 \%$ & $1.191 \pm 0.619$ \\
C.L. for the slope $\left(\mathrm{b} \pm \mathrm{ts}_{\mathrm{b}}\right)$ at $95 \%$ & $437.37 \pm 21.374$ \\
Limit of detection- LOD, $\mu \mathrm{g} \cdot \mathrm{mL}^{-1}$ & 0.005 \\
Limit of quantitation $-\mathrm{LOQ}, \mu \mathrm{g} \cdot \mathrm{mL}^{-1}$ & 0.0165 \\
\hline
\end{tabular}

Table 2. Analytical numbers of merit of the deferoxamine-Fe complex estimation using DPP methods

\begin{tabular}{lc}
\hline Parameters & Values \\
\hline Peak potential, $\mathrm{E}_{\mathrm{p}}(\mathrm{V})$ & -0.385 \\
Complex M:L ratio & $1: 1$ \\
Concentration range $(\mathrm{M})$ & $1.25 \times 0^{-6}-2.5 \times 10^{-5}$ \\
Regression equation $\mathrm{y}=\mathrm{bx}-\mathrm{a}$ & $\mathrm{Y}=4.7849 \mathrm{X}+2.8841$ \\
Correlation coefficient ${ }^{\circ}$ & 0.9985 \\
Linearity $\left(\mathrm{R}^{2}\right)$ & 0.9971 \\
Slop (b) & 4.7849 \\
Intercept (a) & 2.8841 \\
Standard deviation of regression line $\left(\mathrm{S}_{\mathbf{y} / \mathbf{x}}\right)$ & 1.11 \\
Standard deviation of intercept $\left(\mathrm{S}_{\mathrm{a}}\right)$ & 0.6998 \\
Standard deviation of slope $\left(\mathrm{S}_{\mathrm{b}}\right)$ & 0.0497 \\
C.L. for the intercept $\left(\mathrm{a} \pm\right.$ ts $\left.\mathrm{s}_{\mathrm{a}}\right)$ at $95 \%$ & $2.8841 \pm 1.798$ \\
C.L. for the slope (b $\left.\pm \mathrm{ts}_{\mathrm{b}}\right)$ at $95 \%$ & $4.7849 \pm 0.127$ \\
Limit of detection- $\mathrm{LOD}, \mathrm{M}$ & $0.1 \times 0^{-6}$ \\
Limit of quantitation $-\mathrm{LOQ}, \mathrm{M}$ & $0.3 \times 0^{-6}$ \\
\hline
\end{tabular}

The accuracy and precision of the method for the determination of deferoxamine and deferoxamine-Fe complex were confirmed. Various standard samples were prepared and analysis $(n=5)$, Table 3 and 4 respectively.

Table 3. Analysis of standard deferoxamine

\begin{tabular}{ccccccccc}
\hline $\begin{array}{c}\text { Initial conc. } \\
\text { Mg.mL } \mathrm{mL}^{-1}\end{array}$ & $\begin{array}{c}\text { Found conc. } \\
\mathrm{Mg} \cdot \mathrm{mL}^{-1}\end{array}$ & $\begin{array}{c}\text { Absolute } \\
\text { error }\end{array}$ & $\% \mathrm{RE}$ & $\% \mathrm{Rec}$ & $\mathrm{SD}$ & $\begin{array}{c}\frac{\mathrm{SD}}{\sqrt{\mathrm{n}}} \\
\begin{array}{c}\text { C.L of } \\
\text { the mean }\end{array}\end{array}$ & $\% \mathrm{RSD}$ \\
\hline 0.01 & 0.0096 & -0.0004 & -4.00 & 96.0 & 0.0008 & $3.5 \times 10^{-4}$ & $\begin{array}{c}0.0096 \\
\pm 0.0008\end{array}$ & 0.87 \\
0.03 & 0.0286 & -0.0014 & -4.66 & 95.3 & 0.0003 & $1.3 \times 10^{-4}$ & $\begin{array}{c}0.0286 \\
\pm 0.0003\end{array}$ & 1.24 \\
0.05 & 0.0491 & -0.0009 & -1.80 & 98.2 & 0.0001 & $4.4 \times 10^{-5}$ & $\begin{array}{c}0.0491 \\
\pm 0.0001\end{array}$ & 0.34 \\
\hline
\end{tabular}


Table 4. Analysis of deferoxamine-Fe complex

\begin{tabular}{|c|c|c|c|c|c|c|c|c|}
\hline $\begin{array}{c}\text { Initial conc. } \\
\mu \mathrm{g} \cdot \mathrm{mL}^{-1}\end{array}$ & $\begin{array}{l}\text { Found conc. } \\
\mu \mathrm{g} \cdot \mathrm{mL}^{-1}\end{array}$ & $\begin{array}{c}\text { Absolute } \\
\text { error }\end{array}$ & $\% \mathrm{RE}$ & $\% \operatorname{Rec}$ & SD & $\frac{\mathrm{SD}}{\sqrt{\mathrm{n}}}$ & $\begin{array}{l}\text { C.L of the } \\
\text { mean }\end{array}$ & $\%$ RSD \\
\hline $2 \times 10^{-6}$ & $1.97 \times 10^{-6}$ & -0.03 & -1.50 & 99.00 & 0.013 & $5.8 \times 10^{-3}$ & $\begin{array}{c}1.97 \times 10^{-6} \\
\pm 0.01\end{array}$ & 0.66 \\
\hline $3 \times 10^{-6}$ & $2.94 \times 10^{-6}$ & -0.06 & -2 & 98.00 & 0.008 & $3.5 \times 10^{-3}$ & $\begin{array}{c}2.94 \times 10^{-6} \\
\pm 0.009\end{array}$ & 0.27 \\
\hline $4 \times 10^{-6}$ & $3.93 \times 10^{-6}$ & -0.07 & -1.75 & 98.25 & 0.012 & $5.3 \times 10^{-3}$ & $\begin{array}{c}3.93 \times 10^{-6} \\
\pm 0.013\end{array}$ & 0.31 \\
\hline
\end{tabular}

$$
* n=5, t=2.57
$$

The proposed DPP method was applied to the determination of deferoxamine and deferoxamine-Fe complex in commercial desferal vial, $500 \mathrm{mg}$. Each sample was treated according to experimental work explained by recommended DPP.

The results show that the actual deferoxamine amounts in commercial desferal vial, $500 \mathrm{mg}$ ranged between 486 to $495 \mathrm{mg}$, which are actually equal to the amount fixed in the original products. The results are presented in Table 5 .

Table 5. Analysis of commercial pharmaceuticals deferoxamine sample

\begin{tabular}{cccccc}
\hline \multicolumn{5}{c}{ Desferal vial-500 mg } \\
\hline $\begin{array}{c}\text { Initial conc. } \\
\mu \mathrm{g} . \mathrm{mL}^{-1}\end{array}$ & $\begin{array}{c}\text { Measured } \\
\text { Conc. } \mu \mathrm{g} . \mathrm{mL}^{-1}\end{array}$ & $\begin{array}{c}\text { Measurement } \\
\text { of drug }\end{array}$ & \%Rec. & SD & \%RSD \\
\hline & 0.0495 & 495 & 99.00 & & \\
0.05 & 0.0491 & 491 & 98.20 & & \\
& 0.0486 & 486 & 97.35 & 0.0004 & \multirow{2}{*}{0.92} \\
& 0.0495 & 495 & 99 & & \\
& 0.0486 & 486 & 97.35 & & \\
\hline
\end{tabular}

Number of transferred electrons and actual $E_{1 / 2}$

The definite number of transfer electrons in a reversible/irrevrsible electrode procedure and the real value of $\mathrm{E}^{1 / 2}$ was designed using Heyrovsky-Ilkovic equation which clarify the cathode reduction wave as reversible process at $25^{\circ} \mathrm{C}^{16}$.

$$
\mathrm{E}_{\text {applied }}=\mathrm{E}_{1 / 2}-(0.0591 / \mathrm{n}) \log (\mathrm{i} / \mathrm{id}-\mathrm{i})
$$

This equation describes the relationship between diffusion current and applied potential for a reversible/irrevrsible reaction. Number of electrons (n) can be proved from the plot of $\log (\mathrm{i} / \mathrm{id}-\mathrm{i})$ versus applied voltage (E) at set group concentrations. For a reversible process, (n) appear to be a exact number, while an incomplete number for (n) show an irreversible process ${ }^{17}$. The actual peaks voltage $\mathrm{E}_{1 / 2}$ calculated of deferoxamine and deferoxamine-Fe complex were -1.623 and $-0.384 \mathrm{~V}$ and two electrons were required for the reduction (Figures 11 and 12).

Deferoxamine has five carbonyl groups while deferoxamine-Fe complex has only two free carbonyl groups, as the results showed, the more easily carbonyl group reduced to give hydroxyl group with two electrons transfer (Figure 13). 


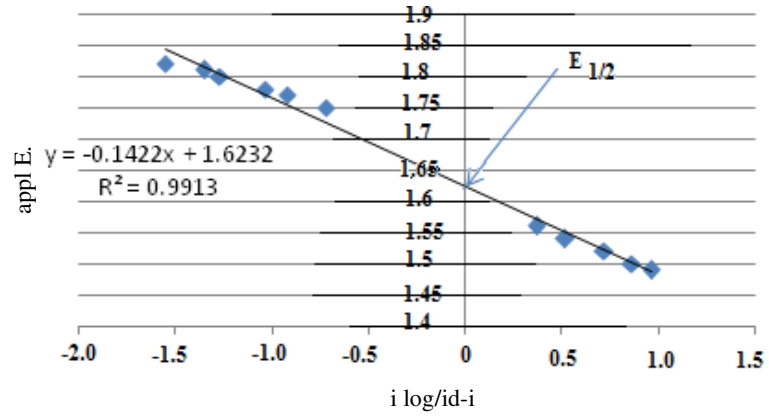

Figure 11. Effect of $E$ applied on the variant $\log (\mathrm{i} / \mathrm{id}-\mathrm{i})$ by Heyrovsky-Ilkovic equation at $0.05 \mu \mathrm{g} \cdot \mathrm{mL}^{-1}$ deferoxamine

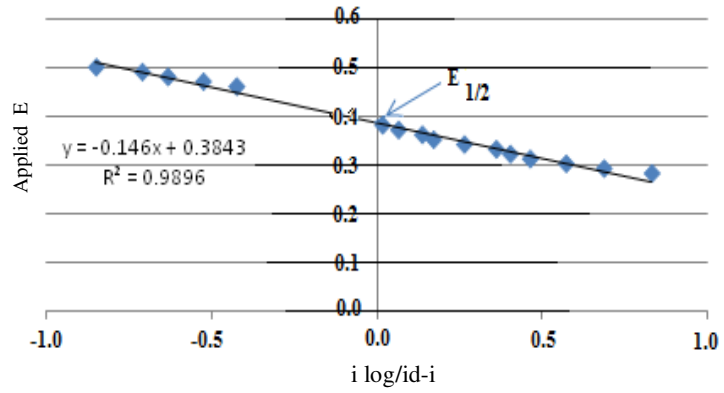

Figure 12. Effect of $E$ applied on the difference $\log (\mathrm{i} / \mathrm{id}-\mathrm{i})$ with Heyrovsky-Ilkovic equation at $2.5 \times 10^{-5} \mathrm{M}$ deferoxamine-Fe complex

Deferoxamine-Fe(III) complex

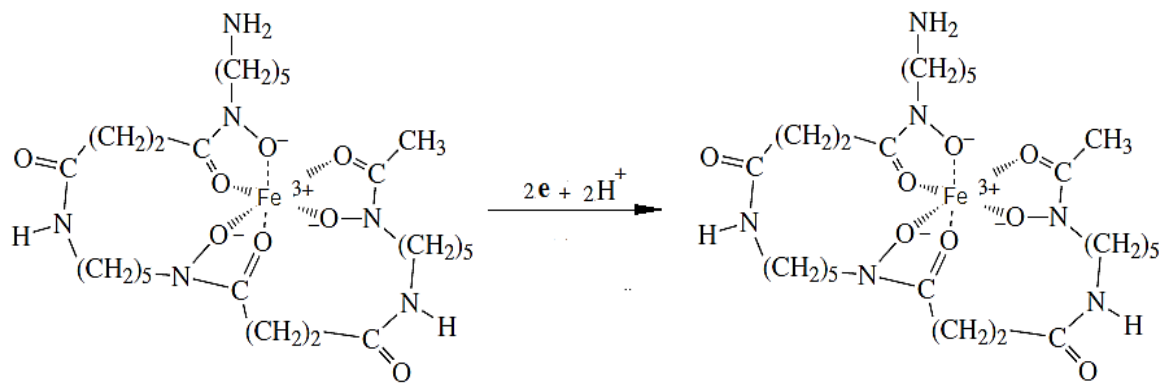

Deferoxamine

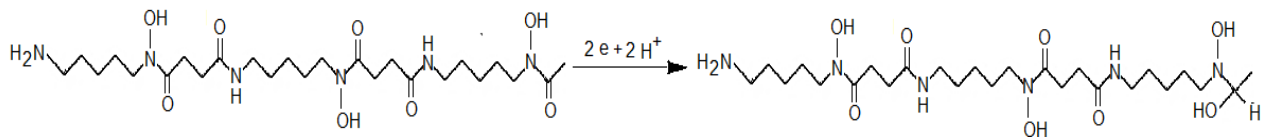

Figure 13. Suggested reduction mechanism for deferoxamine and deferoxamine-Fe complex

\section{Conclusion}

This method has clarified that DPP technique has various advantage found suitable for the determination of deferoxamine in the pharmaceutical preparations. The technique proved to be accurate, fast and precise thereby it may be considered as an other techniqe for pharmaceutical analysis. 


\section{References}

1. Deferoxamine Mesylate; Retrieved on February 2018, http://www.genome.jp/dbgetbin/www_bget?dr:D01186

2. Michael L Ott, Desferrioxamine, 311C, Chemistry Botany, Department of Chemistry, University of Iowa, Iowa City, IA 52242, 12, February, 2001.

3. McLaren G D, Muir W A and Keller Meyer RW, Crit Rev Clin Lab Sci., 1983, 19, 205-266; DOI:10.3109/10408368309165764

4. Snow G A, Biochem J., 1969, 115(2), 199-205; DOI:10.1042/bj1150199

5. Yokel Robert A, Coord Chem Rev., 2002, 228(2), 97-113.

6. Randal J Keller, James D Rush and Thomas A Grover, J Inorg Biochem., 1991, 41(4), 269-276; DOI:10.1016/0162-0134(91)80019-E

7. Nascimento, Paulo C et al., Talanta, 2006, 70(3), 540-545.

8. Marcin K, Arthur S, Tomasz B, Michał P M and Ewa Z, J Sep Sci., 2013, 36(4), 665669; DOI:10.1002/jssc.201200683

9. Lehmannl W D and Heinrich H C, Anal Biochem., 1990, 184(12), 219-227; DOI:10.1016/0003-2697(90)90672-V

10. Robert H and Glen D, Bioelectrochem and Bioenergetics, 1989, 22(3), 187-196; DOI:10.1016/0302-4598(89)87038-2

11. Abdel Razak O, Belal S F, Bedair M M and Haggag R S, Talanta, 2003, 59(5), 10611069; DOI:10.1016/S0039-9140(03)00013-4

12 Chandra Mohan, Buffers- A guide for the preparation and use of Buffers in biological systems, EMD Bioscience, Germany, $3^{\text {rd }}$ Edn., 2006.

13. Douglas A Skoog, Donald M West, James F Holler, Stanley R Crouch, Fundamental of Analytical Chemistry, $9^{\text {th }}$ Ed, 2013.

14. Salam A.H. Global Journal of Science Frontier Research: B Chemistry, 2017, 17(1), 27-32.

15. James N M and Jane C M, Statistics and chemometrics for analytical chemistry, Pearson Education Limited, Prentice Hall, $5^{\text {th }}$ Ed, Person Education Limited, Edinburgh Gate, Harlow, England, 2005.

16. Salam A H Al-Ameri and Najlah M H Al-Waeli, Int J Bioanal Methods Bioequival Stud., 2016, 3(1), 47-54; DOI:10.19070/2470-4490-150006

17. Joseph Wang, Analytical Electrochemistry, John Wiley and Sons, Inc., pp. $64,2^{\text {nd }}$ Ed., 2000. 